\title{
Breeding review of Gray-hooded Gull Chroicocephalus cirrocephalus in Brazil with contributions on nests and egg biometry
}

\author{
Rodolfo Teixeira Frias ${ }^{1,2,4}$; Lucas Rocha Melo Porto ${ }^{3,5}$; Luciano Gomes Fischer ${ }^{1,2,6}$ \& Patrícia Luciano Mancini ${ }^{1,2,7}$ \\ 1 Universidade Federal do Rio de Janeiro (UFRJ), Instituto de Biodiversidade e Sustentabilidade (NUPEM). Macaé, RJ, Brasil. \\ 2 Universidade Federal do Rio de Janeiro (UFRJ), Programa de Pós-Graduação em Ciências Ambientais e Conservação (PPG-CiAC). Macaé, RJ, Brasil. \\ ${ }^{3}$ Universidade Estadual do Norte Fluminense (UENF). Campos dos Goytacazes, RJ, Brasil. \\ ${ }^{4}$ ORCID: http://orcid.org/0000-0002-9232-4592. E-mail: rodolfoteixeira26@gmail.com \\ ${ }^{5}$ ORCID: http://orcid.org/0000-0002-3639-8378. E-mail: luromepo@gmail.com \\ ${ }^{6}$ ORCID: http://orcid.org/0000-0002-7219-4364. E-mail: luciano.fischer@gmail.com \\ 7 ORCID: http://orcid.org/0000-0002-4449-356X.E-mail: patmancinibr@yahoo.com.br
}

\begin{abstract}
The Gray-hooded Gull (Chroicocephalus cirrocephalus) is a seabird distributed in almost all South American countries. However, breeding information on the species in Brazil is scarce. In this study, a literature review and searches in online databases (WikiAves and eBird) were carried out to gather breeding information on the species in the country and new records of nests of the Gray-hooded Gull were registered on the northern coast of the Rio de Janeiro state. Literature review indicated breeding records in Rio Grande do Sul, Rio de Janeiro and Rio Grande do Norte states. On WikiAves, 19 records of the species with nests, eggs, chicks and breeding colonies were reported between 2009 and 2020, in Macau, Rio Grande do Norte and one adult hatching at Rio Grande do Sul. In August 2019, two nests were recorded at Ubatuba lagoon ( $22^{\circ} 09^{\prime} S$ and $41^{\circ} 18^{\prime} \mathrm{W}$ ) in the Restinga de Jurubatiba National Park, in the Quissamã municipality in Rio de Janeiro. The nests were described and monitored during five weeks. Each nest contained two eggs and was built with the grass Paspalum vaginatum. Over time, the eggs were degraded and disappeared from the nests, without signs of hatching and possible predation. This study compiles for the first time all the breeding information on the species in Brazil and contributes with data about nests and egg biometry.
\end{abstract}

Key-Words. Seabirds; Coastal lagoons; Restinga de Jurubatiba National Park; Laridae; WikiAves.

\section{INTRODUCTION}

Gulls are cosmopolitan seabirds of the Laridae family (Charadriiformes) and more than 50 species are distributed across all continents, with eight of them occurring in Brazil (Sibley \& Monroe, 1990; Sick, 1997). Some species are residents such as the Kelp Gull (Larus dominicanus) and Gray-hooded Gull (Chroicocephalus cirrocephalus), while others are vagrants as the Frankiln's Gull (Leucophaeus pipixcan) from the Northern hemisphere (Canada and USA) and the Olrog's Gull (Larus atlanticus) from southern South America (Sick, 1997; Piacentini et al., 2015; Yorio, 2020).

The Gray-hooded Gull is found in South America and Africa and two subspecies are recognized (Grantsau, 2010; Clements et al., 2015; Burger et al., 2020). The South American subspecies (C. cirrocephalus cirrocephalus) is slightly larger and paler than the African one (C. cirrocephalus poiocephalus) and the gene flow across the Atlantic Ocean seems improbable (Burger et al.,
2020). In South America, the species is mainly abundant in the south (Sibley \& Monroe, 1990; Sick, 1997; Burger et al., 2020). In Brazil it is distributed along the coast and occasionally more inward in the south of Mato Grosso do Sul state (Belton, 1984; Sick, 1997; Ruschel \& Costa, 2003; Azevedo-Júnior et al., 2004; Scherer-Neto et al., 2011; Leal et al., 2013; Tavares et al., 2013). Part of the $C$. cirrocephalus population are individuals from other colonies (Barbieri et al., 2010) as the ones breeding in Argentina (Burger et al., 2020), while another part are resident birds. However, despite its wide distribution on the Brazilian coast, breeding information about the species is scarce.

Seagulls are associated with aquatic habitats, such as lakes and marine environments (Schreiber \& Burger, 2001) and breeding colonies, even in coastal areas, are found close to freshwater habitats (Du Toit et al., 2003). In the breeding period C. cirrocephalus builds nests in open areas or in floating vegetation, on rocky islands and flooded soils in the interior of the continents (Burger et al., 
2020). In South America, the main breeding populations are in northeast Argentina, but the species also breeds in north Paraguay, Uruguay, north, south and southeast of Brazil (Maurício et al., 2013; Tavares et al., 2013; Burger et al., 2020). In Brazil, the first breeding record of the species was in Rio Grande do Sul state (RS) in November 1995 (Maurício et al., 2013), in Rio Grande do Norte in June and July 1999, April and June 2000 (Azevedo-Júnior et al., 2000, 2004) and in Rio de Janeiro state in Farol de São Thomé, Campos dos Goytacazes, in September 2008 (Tavares et al., 2013). This study aims to review the literature and online databases (WikiAves and eBird) regarding the Gray-hooded Gull breeding information in Brazil and describe nests and eggs of the species from the northern of Rio de Janeiro state.

\section{MATERIAL AND METHODS}

\section{Study area and sampling}

The databases WikiAves and eBird were accessed to search for breeding records of the species in Brazil. In WikiAves an advanced search - species name (Chroicocephalus cirrocephalus) + photo content (egg and nest); age (chick) and observed action (mating, hatching, feeding chicks and building a nest). For eBird - a spreadsheet with records of the species in Brazil was used searching for breeding information in the observation section.

The nests additionally observed were in the Restinga de Jurubatiba National Park (RJNP), which has an area of 15 thousand hectares and 18 coastal lagoons in the north of Rio de Janeiro state. The region is warm and rainy, with the dry season in Austral autumn and winter. The average annual temperature is $24^{\circ} \mathrm{C}$ and precipitation varies between 35 and $180 \mathrm{~mm}$ (Fischer et al., 2007). The Ubatuba lagoon is located on the northern limit of the RJNP $\left(22^{\circ} 09^{\prime} \mathrm{S}\right.$ and $\left.41^{\circ} 18^{\prime} \mathrm{W}\right)$ (Fig. 1).

The nests were georeferenced and monitored for five weeks. The initial observation of the nests was done with binoculars (Nikon Prostaff 10x42), telescope (Celestron $22-66 \times 100)$ and camera (Nikon P600). Then, for each nest, the following parameters were recorded: (i) type of material used to build the nest; (ii) diameter and height of the nest; and (iii) number of eggs and their diameter, length and mass. The egg biometry was measured with a caliper $(0.1 \mathrm{~mm})$ and the measurements of the nests with a measuring tape and ruler ( $1 \mathrm{~mm}$ ).

\section{RESULTS}

In the literature review, no new information was found on the species breeding in Brazil, only the ones cited earlier (Azevedo-Júnior et al., 2000, 2004; Maurício et al., 2013; Tavares et al., 2013). On WikiAves, 19 records of the species with nests, eggs, chicks and breeding colonies were reported between 2009 and 2020, in Macau, Rio Grande do Norte and one record of a pair hatching in Candiota, in Rio Grande do Sul (Table 1, Fig. 1). There was no breeding evidence on the eBird platform, only of an immature individual on the Japonês Island, in Cabo Frio, Rio de Janeiro state, on the $14^{\text {th }}$ of January 2020 reported by Helberth Peixoto.

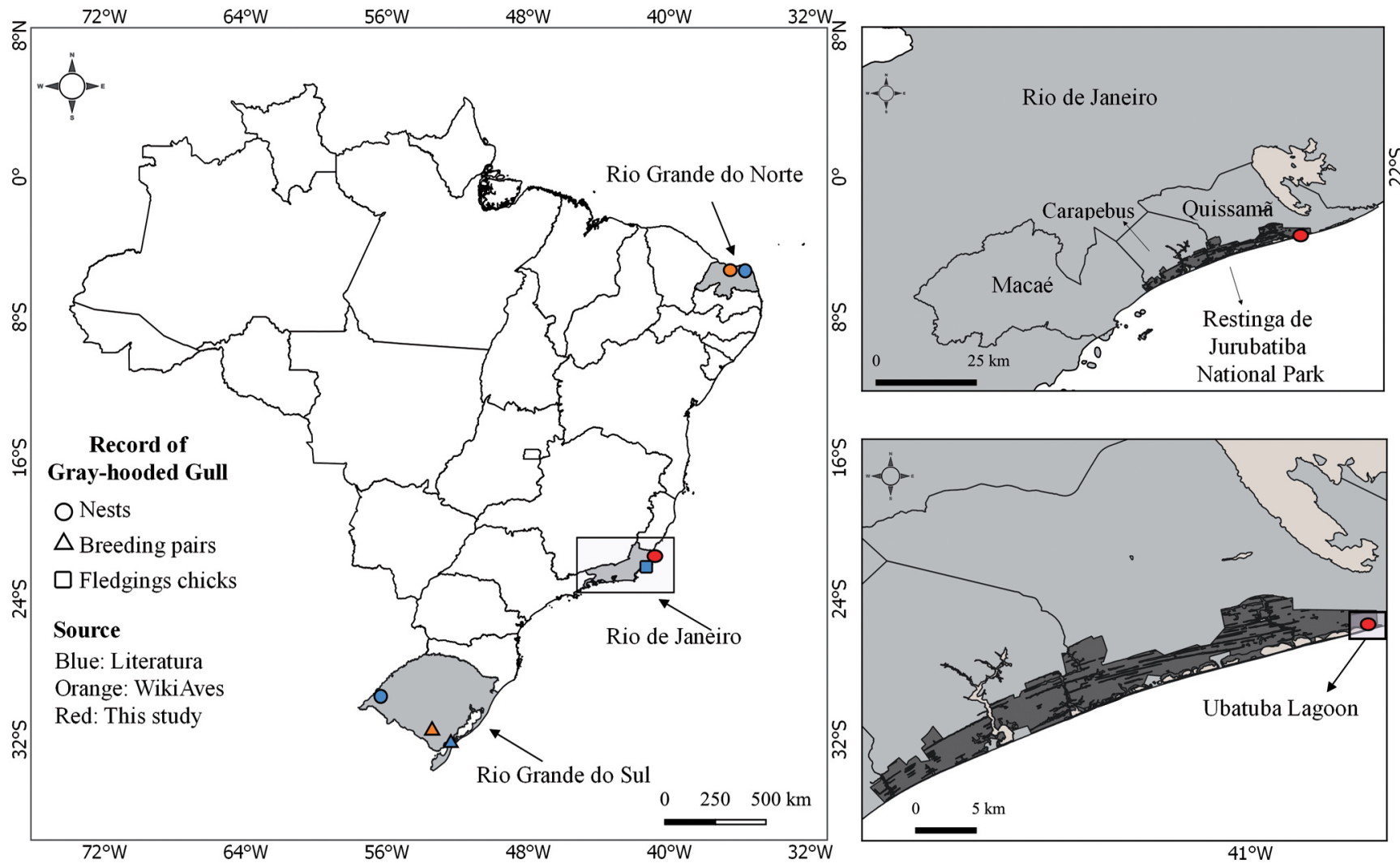

Figure 1. Breeding records of the Gray-hooded Gull (Chroicocephalus cirrocephalus) in Brazil. Nests (circles), breeding pairs (triangle), fledging chicks (square). 
Table 1. Breeding records of the Gray-hooded Gull (Chroicocephalus cirrocephalus) on WikiAves. Location: Municipality and state. $\mathrm{RN}=$ Rio Grande do Norte state, $\mathrm{RS}=$ Rio Grande do Sul state.

\begin{tabular}{cccccc}
\hline Nr. & Local & Date & Nest Content/Action & Author & $\begin{array}{c}\text { Record } \\
\text { Number }\end{array}$ \\
\hline 1 & Macau/RN & $18 / 07 / 2009$ & Adult hatching & Bruno França & WA357918 \\
2 & Macau/RN & $19 / 07 / 2009$ & 3 eggs & Bruno França & WA357927 \\
3 & Macau/RN & $19 / 07 / 2009$ & 3 eggs & Mauro Pichorim & WA3258299 \\
4 & Macau/RN & $19 / 07 / 2009$ & 4 eggs & Mauro Pichorim & WA3258300 \\
5 & Macau/RN & $19 / 07 / 2009$ & 1 nestling & Mauro Pichorim & WA3258305 \\
6 & Macau/RN & $23 / 07 / 2011$ & 1 nestling & Tonny Marques & WA427421 \\
7 & Macau/RN & $05 / 06 / 2012$ & 2 eggs & Mauro Pichorim & WA3257151 \\
8 & Macau/RN & $29 / 03 / 2014$ & 1 egg + 1 nestling & Pedro Vitor & WA2018575 \\
9 & Macau/RN & $29 / 03 / 2014$ & 1 fledging & Pedro Vitor & WA2014162 \\
10 & Macau/RN & $29 / 03 / 2014$ & Adult hatching & Pedro Vitor & WA2014163 \\
11 & Macau/RN & $18 / 03 / 2015$ & 1 egg & Jorge Dantas & WA2451288 \\
12 & Macau/RN & $29 / 02 / 2016$ & Adult hatching & Jorge Dantas & WA2040617 \\
13 & Candiota/RS & $30 / 08 / 2017$ & Adult hatching & Rudimar de Matos & WA2678798 \\
14 & Macau/RN & $07 / 02 / 2018$ & Adult hatching & Anderson Salvador & WA2893640 \\
15 & Macau/RN & $17 / 04 / 2019$ & 1 nestling & Pedro Pierote & WA3410509 \\
16 & Macau/RN & $21 / 07 / 2019$ & 1 egg hatching + 2 eggs & Pedro Pierote & WA3494930 \\
17 & Macau/RN & $21 / 07 / 2019$ & 1 fledging & Pedro Pierote & WA3494927 \\
18 & Macau/RN & $22 / 07 / 2019$ & 1 nestling + 1 egg & Pedro Pierote & WA3726060 \\
19 & Macau/RN & $06 / 06 / 2020$ & 1 nestling + 1 egg & Pedro Pierote & WA3832258 \\
20 & Macau/RN & $07 / 06 / 2020$ & 1 fledging & Pedro Pierote & WA3832271 \\
\hline & & & & &
\end{tabular}

Breeding signs of the species in RJNP began with juveniles and adults with breeding plumage in April and December 2019 (Fig. 2).

On August 29, 2019, we recorded two C. cirrocephalus nests with eggs in Ubatuba lagoon in RJNP. The aggressive defense behavior of a $C$. cirrocephalus towards a Great Egret (Ardea alba) drew our attention. In one of the nests, we observed one egg inside and the other lying on top of the nearby vegetation, confirming the attempt of A. alba to prey on the egg (Fig. 3).

The two nests were found on the same day, 116.6 meters apart with 2 eggs each. The nests were in a colony of the White-backed Stilt Himantopus melanurus. Both nests were built on the surrounding water, $11 \mathrm{~cm}$ deep, structured by Paspalum vaginatum Sw., a grass species present in all the RJNP lagoons and also used to build
Table 2. Biometry of Gray-hooded Gull (Chroicocephalus cirrocephalus) eggs, recorded in the Ubatuba lagoon, in the Restinga de Jurubatiba National Park, Quissamã, Rio de Janeiro state.

\begin{tabular}{|c|c|c|c|c|}
\hline \multirow{2}{*}{ Measures } & \multicolumn{2}{|c|}{ Nest 1} & \multicolumn{2}{|c|}{ Nest 2} \\
\hline & egg 1 & egg 2 & egg 1 & $\operatorname{egg} 2$ \\
\hline Length (mm) & 57 & 56 & 59 & 56 \\
\hline Diameter (mm) & 39 & 39 & 35 & 37 \\
\hline Date & \multicolumn{4}{|c|}{ egg mass (g) } \\
\hline August $29^{\text {th }}$ & 40.1 & 36.9 & 38.6 & 38.2 \\
\hline September $5^{\text {th }}$ & - & 40.1 & 38 & 40.6 \\
\hline September $10^{\text {th }}$ & - & 41.9 & 37.4 & - \\
\hline September $19^{\text {th }}$ & - & 46.3 & * & - \\
\hline September $24^{\text {th }}$ & - & 45.6 & - & - \\
\hline 0ctober $5^{\text {th }}$ & - & - & - & - \\
\hline
\end{tabular}

the nests itself. The nest heights were 23 and $41 \mathrm{~cm}$ and the diameters were 22.5 and $23 \mathrm{~cm}$ respectively. The egg masses were monitored once a week during five weeks (Table 2). The mean egg length was $57 \pm 1.2 \mathrm{~cm}$ and mean breadth was $37.4 \pm 1.7 \mathrm{~cm}$. In the last monitoring, on October $5^{\text {th }}, 2019$, nest 1 was empty, with no apparent hatching or chick presence, and no adults were observed nearby.

\section{DISCUSSION}

Breeding information on the Gray-hooded Gull is practically nonexistent in Brazil. Therefore, the information gathered in this study is an essential contribution to both breeding records of the species as well as providing detailed information on the egg biometry and the first study to compile all existing information on the breeding of this species in the country.

Based on WikiAves data, it is clear that Rio de Janeiro and Rio Grande do Norte are breeding sites of the species in Brazil, as well as Rio Grande do Sul (Maurício et al., 2013). However these areas are still classified as "extant nonbreeding" in the species distribution map on the IUCN and BirdLife International websites (BirdLife International, 2018, 2020). In the Birds of the World (on-
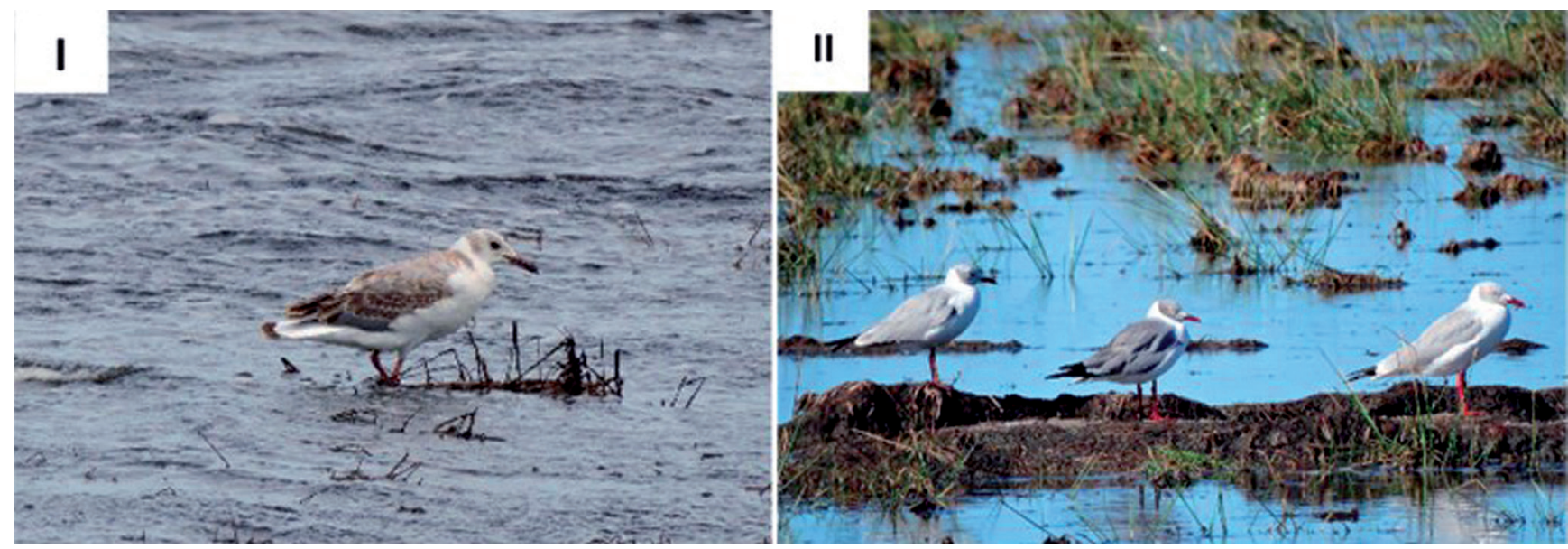

Figure 2. (I) Juvenile of Gray-hooded Gull (Chroicocephalus cirrocephalus) in Visgueiro lagoon, on December $5^{\text {th }}$, 2019. (II) Adults with breeding plumage on April $14^{\text {th }}$, 2019. Both images from Restinga de Jurubatiba National Park, in Quissamã, on the northern coast of the Rio de Janeiro state. 
line publication) the Rio Grande do Norte site does not appear on the South American map (Burger et al., 2020). These platforms should be updated with the information gathered in this study.

According to the review of online platforms, in northeast Brazil the mean clutch size is two eggs, considering the eggs and nestlings in 13 nests. This result is similar to the species nesting in Ubatuba lagoon and C. c. poiocephalus in east Africa, with mean clutch size of 2.4 eggs (McInnes, 2006). In the literature review a breeding colony, with an area of $2.200 \mathrm{~m}^{2}$, was recorded at Salina Diamante Branco, in the municipality of Galinhos, RN, in July 1999. In the colony there were 27 nests with one egg, 20 nests with two eggs, and 35 nests with one chick and one egg. This was the first breeding record of the species in Northeast Brazil and individuals with breeding plumage were observed between March and August 1999 (Azevedo-Júnior et al., 2000). Other gull species lay between 1 to 4 eggs, with mean clutch size of 2.6 eggs in Brown-hooded Gull (Burger et al., 2020) or varying between 1.9 to 2.3 eggs in Kelp Gull (Dantas \& Morgante, 2010).

In this study, although the eggs were degraded or predated over time, the egg mass increased almost $10 \mathrm{~g}$ in 21 days ( 36.9 to $46.3 \mathrm{~g}$ ) in one egg, indicating its active development and an incubation period around 20 days. Similarly, the mean incubation period was 24.9 days for C. c. poiocephalus in Africa (Mclnnes, 2006) and 22.7 to 24.1 days for L. dominicanus in Brazil (Dantas \& Morgante, 2010).

Paspalum vaginatum used to build the nest is a dominant grass around Ubatuba lagoon and the same grass species used by C. c. poiocephalus in Lane Island, Africa (McInnes, 2006). In Laguna Chica in Peru, Gray-hooded Gull used feathers of Chilean Flamingo (Phoenicopterus chilensis) that were common in the lagoons (Tovar \& Ashmole, 1970). Thus, the species use common and abundant items in the environment (as grass, feather,
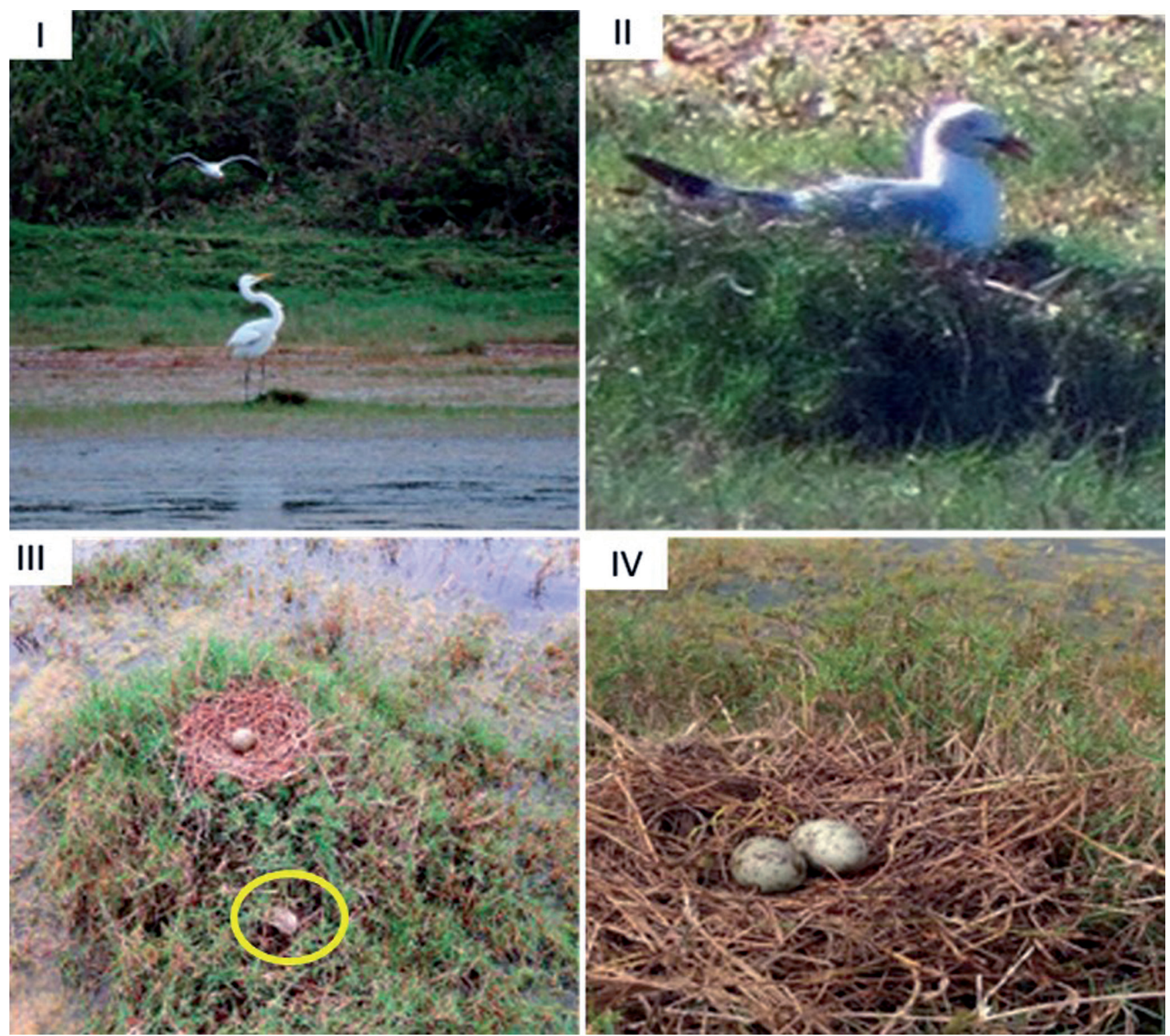

Figure 3. (I) Gray-hooded Gull Chroicocephalus cirrocephalus attacking a Great egret Ardea alba in the Ubatuba lagoon; (II) C. cirrocephalus nesting; (III) First C. cirrocephalus nest with an egg inside and other fallen nearby (highlighted by the yellow circle) after predation attempt by Ardea alba; (IV) Second nest with two eggs in the Ubatuba lagoon, at Restinga de Jurubatiba National Park, Quissamã, on the northern coast of the Rio de Janeiro state. 
etc) to build their nests. The diameter of the nests in this study were smaller $(\approx 23 \mathrm{~cm})$ than the mean diameter ( $28.5 \pm 7.2 \mathrm{~cm}, \mathrm{n}=108)$ of C. c. poiocephalus from two areas in Africa (Mclnnes, 2006). The water around the nests was $11 \mathrm{~cm}$ deep in this study, similar to the $9 \mathrm{~cm}$ depth of nests in Laguna Chica in Peru (Tovar \& Ashmole, 1970).

Gray-hooded Gulls breed colonially and the nearest-neighbour nest distance varies from less than $1 \mathrm{~m}$ to a few meters apart (Duffy \& Atkins, 1979; Burger et al., 2020), however in this study nests were $116.6 \mathrm{~m}$ apart, equivalent to the nest distance up to $100 \mathrm{~m}$, in Mauritania, Africa (Burger et al., 2020). While in South Africa, in four Gray-hooded Gull colonies the mean nearest-neighbour distance ranged from 0.8 to $10 \mathrm{~m}$ (maximum of $75 \mathrm{~m}$ ) (Mclnnes, 2006). Also, the Gray-hooded Gull in RJNP nested on the border of a Himantopus melanurus colony and the nearest-neighbour nest distance from this species was $57 \mathrm{~m}$. Colonial nesting seabirds seem to disperse to other colonies due to the presence of predators (Clode, 1993; Oro et al., 1999). Predation in RJNP is a constant threat in the area, as there are mammals and many birds that may feed on eggs and chicks, as herons, vultures, hawks, etc (authors obs.). However, chick loss due to predation by the neighboring gull pairs may be a more important factor than other predators (Paynter, 1949; Parsons, 1971) because chicks may invade the neighbour's space, and adults become more active to defend their territory (Hunt \& Hunt, 1975). This may explain why the Gray-hooded Gull nests were so far apart, as reported here.

In RJNP, the dimensions of the eggs were larger than C. c. poiocephalus in Africa (mean length $51.8 \pm 1.96$ and mean breadth $36.3 \pm 1.41 \mathrm{~cm}$ ) (Mclnnes, 2006). The difference of the egg dimension may be due to the morphological variations of each population, since the South American individuals are larger than African ones and/or because the differences in food availability between the areas (Mills, 1979; Sydeman \& Emslie, 1992). The northern littoral of Rio de Janeiro state has several nearby coastal lagoons, which undergo changes in their conformation according to the season and are important for many waterbird species. The dry season (April to September) favors an environment with greater productivity, and abundant food resources. The shallow lagoons facilitate foraging for the gull species searching for fish and invertebrates in this period, which is when the Gray-hooded Gull nests at RJNP (Macedo-Soares et al., 2010; Lisboa et al., 2011; Tavares et al., 2013). Nevertheless, information on egg size from other Gray-hooded Gull's colonies in Brazil are essential to elucidate these differences.

Although it was not possible to follow the further breeding stages of the Gray-hooded Gull, it is important to emphasize that the northern littoral of Rio de Janeiro state continues to be used for nesting 11 years after the first breeding evidence.

\section{CONCLUSION}

This study provides information regarding the breeding areas of Gray-hooded Gull in Brazil, and may contrib- ute to update the information on the main online platforms such as IUCN, BirdLife, etc. The study also indicates that the species continues to nests in the northern littoral of Rio de Janeiro state after 11 years of its first breeding evidence. Furthermore, the biometry of eggs and nests are the first ones reported for the species in Brazil and may be used for future investigations on the species' breeding biology.

\section{AUTHOR'S CONTRIBUTION}

Rodolfo Teixeira Frias and Lucas Rocha Melo Porto: field sampling, compilation of data from the WikiAves and eBird database; bibliographic review, tables and figures preparation, initial writing and revision of the manuscript. Luciano Gomes Fischer: Review of the manuscript and contributions on the taxonomic approach. Patricia Luciano Mancini: Results interpretation, writing and final review of the manuscript. All authors participated effectively in the discussion of the results.

\section{ACKNOWLEDGEMENTS}

The authors thank M. Pessanha (head of the Restinga Jurubatiba National Park), M.C. Santos, A.N. Miranda and A. Maynhone for all the logistical support at RJNP; T.P. Xavier for kindly drawing up the map. M.P. de Araújo for grass identification. To citizen-scientists who made the photos of birds available on WikiAves and to Yasmina Shah Esmaeili for the English revision of the manuscript. R.F. Teixeira is supported by a Fundação de Amparo à Pesquisa no Rio de Janeiro (FAPERJ - DSC - Proc. № 200.856/2018) scholarship and currently receives at scholarship from Coordenação de Aperfeiçoamento de Pessoal de Nível Superior - Brasil (CAPES) Proc. 88887.505354/2020-00, Chamada CNPq/Capes/FAPs/BC - Fundo Newton - Pesquisa Ecológica de Longa Duração - PELD № 15/2016. This study was partially supported by FUNBIO under a Grant Pesquisa Marinha \& Pesqueira, contract 015/2017 through L.R.M. Porto scholarship within the "Projeto Costões Rochosos: Ecologia, Impactos e conservação nas Regiões dos Lagos e Norte Fluminense". This study was financed in part by CAPES, Finance Code 001 through a PNPD scholarship to P.L. Mancini.

\section{REFERENCES}

Azevedo-Júnior, S.M.; Larrazábal, M.E. \& Pena, 0. 2000. Reprodução e censo de Larus cirrocephalus no Rio Grande do Norte, Brasil. In: Congresso Brasileiro de Zoologia, 23․ Resumos. Cuiabá, Sociedade Brasileira de Zoologia p. 490.

Azevedo-Júnior, S.M.; Larrazábal, M.E. \& Pena, 0. 2004. Aves aquáticas de ambientes antrópicos (salinas) do Rio Grande do Norte, Brasil. In: Branco, J.0. (Eds.). Aves marinhas insulares brasileiras: bioecologia e conservação. Itajaí, Editora UNIVALI. p. 255-266.

Barbieri, E.; Gonçalves, C.A.; Silveira, L.F. \& Cortez-Kiyohara, A.L.L. 2010. Registros de duas aves marinhas inéditas no estado de São Paulo, Brasil: 
Chroicocephalus cirrocephalus e Anous minutus (Charadriiformes). Revista Brasileira de Ornitologia, 18: 242-244.

Belton, W. 1984. Birds of Rio Grande do Sul, Brazil. Bulletin of American Museum of Natural History, 178: 371-361.

BirdLife International. 2018. Larus cirrocephalus. A Lista Vermelha da IUCN de Espécies Ameaçadas 2018. Available: https://www.iucnredlist.org/specie s/22694387/132547419\#geographic-range. Access: 01/02/2020.

BirdLife International. 2020. Ficha técnica da espécie: Larus cirrocephalus. Available: http://datazone.birdlife.org/species/factsheet/grey-headedgull-larus-cirrocephalus/distribution. Access: 01/02/2020.

Burger, J.; Gochfeld, M.; Kirwan, G.M. \& Garcia, E.F.J. 2020. Gray-hooded Gull (Chroicocephalus cirrocephalus). In: Del Hoyo, J.; Elliott, A.; Sargatal, J.; Christie, D.A. \& Juana, E. de. (Eds.). Birds of the World. Ithaca, NY, Cornell Lab of Ornithology.

Clements, J.F.; Schulenberg, T.S.; lliff, M.J.; Roberson, D.; Fredericks, T.A.; Sullivan, B.L. \& Wood, C.L. 2015. The eBird/Clements checklist of birds of the world. Available: http://www.birds.cornell.edu/clementschecklist/ download. Access: 10/07/2020.

Clode, D. 1993. Colonially nesting seabirds: predators or prey? Trends in Ecology and Evolution, 8(9): 336-338.

Dantas, G.P.M. \& Morgante, S.J. 2010. Breeding biology of Kelp Gulls on the Brazilian Coast. The Wilson Journal of Ornithology, 122(1): 39-45.

Du Toit, M.; Boere, G.C.; Cooper, J.; DE Villiers, M.S.; Kemper, J.; Lenten, B.; Petersen, S.L.; Simmons, R.E.; Underhill, L.G.; Whittington, P.A. \& Byers, 0. 2003. Conservation assessment and management plan for Southern African Seabirds. Cape Town, Avian Demography Unit \& Apple Valley: IUCN/SSC Conservation Breeding Specialist Group. 205p.

Duffy, D.C. \& Atkins, N. 1979. A second breeding record for the grey-hooded gull (Larus cirrocephalus) on the coast of Peru. The Condor, 81:219.

Fischer, C.F.; Nunes, M.F.S.Q.C. \& Campos, D.P. 2007. Contextualização da Unidade de Conservação: Plano de Manejo do Parque Nacional Restinga de Jurubatiba. Rio de Janeiro, Encarte. 670p.

Grantsau, R. 2010. Guia completo para identificação das aves do Brasil. São Carlos, SP, Vento Verde.

Hunt, G.L. \& Hunt, M.W. 1975. Reproductive ecology of the Western Gull: the importance of nest spacing. The Auk, 92(2): 270-279.

Leal, S.; Serapião, L.C.H. \& Pereira, G.A. 2013. Registros documentados da gaivota-de-franklin Leucophaeus pipixcan (Wagler, 1831) no Nordeste do Brasil e da gaivota-de-cabeça-cinza Chroicocephalus cirrocephalus (Vieillot, 1817) nos estados de Alagoas e Pernambuco. Revista Brasileira de Ornitologia, 21: 105-108.

Lisboa, L.K.; Silva, A.L.L. \& Petrucio, M.M. 2011. Aquatic invertebrate's distribution in a freshwater coastal lagoon of southern Brazil in relation to water and sediment characteristics. Acta Limnologica Brasiliensia, 23: 119-217.

Macedo-Soares, P.H.M.; Petry, A.C.; Farjalla, V.F. \& Camaraschi, E.P. 2010. Hydrological connectivity in a coastal inland systems: lessons from a Neotropical fish metacommunity. Ecology of Freshwater, 19: 7-18.
Maurício, G.N.; Bencke, G.A.; Repenning, M.; Dias, R.A.; Machado, D. \& Bugoni L. 2013. Review of the breeding status of birds in Rio Grande do Sul, Brazil. Iheringia, Série Zoologia, 103: 163-84.

McInnes, A.M. 2006. Biology of the Grey-headed Gull Larus cirrocephalus in South Africa. (Masters Dissertation). School of Biological and Conservation Sciences at the University of KwaZulu-Natal Pietermaritzburg, South Africa.

Mills, J.A. 1979. Factors affecting the egg size of Red-billed Gulls Larus novaehollandiae scopulinus. Ibis, 121:53-67.

Oro, D.; Pradel, R. \& Lebreton, J. 1999. Food availability and nest predation influence life history traits in Audouin's Gull, Larus audouinii. Oecologia, 118: 438-445.

Parsons, J. 1971. Cannibalism in Herring Gulls. British Birds, 64: 528-537.

Paynter, R. 1949. Clutch size and the egg and chick mortality of Kent Island Herring Gulls. Ecology, 30: 146-166.

Piacentini, V.Q.; Aleixo, A.; Agne, C.E.; Maurício, G.N.; Pacheco, J.F.; Bravo, G.A.; Brito, G.R.R.; Naka, L.N.; Olmos, F.; Posso, S.; Silveira, L.F.; Betini, G.S.; Carrano, E.; Franz, I.; Lees, A.C.; Lima, L.M.; Pioli, D.; Schunck, F.; Amaral, F.R.; Bencke, G.A.; Cohn-Haft, M.; Figueiredo, L.F.A.; Straube F.C. \& Cesari, E. 2015. Annotated checklist of the birds of Brazil by the Brazilian Ornithological Records Committee/Lista comentada das aves do Brasil pelo Comitê Brasileiro de Registros Ornitológicos. Revista Brasileira de Ornitologia, 23(2): 91-298.

Ruschel, C. \& Costa, R. 2003. Registros de gaivota-de-cabeça-cinza, Larus cirrocephalus (Vieillot, 1818) no oeste do Rio Grande do Sul. Atualidades Ornitológicas, 111: 11.

Scherer-Neto, P.; Straube, F.C.; Carrano, E. \& Urben-Filho, A. 2011. Lista das aves do Paraná. Curitiba, Hori Consultoria Ambiental. 130p. (Hori Cadernos Técnicos, 2)

Schreiber, E.A. \& Burguer, J. 2001. Biology of marine birds. Boca Raton, FL, CRC Press.

Sibley, C.G. \& Monroe, B.L. 1990. Distribution and taxonomy of Birds of the World. New Havewn, Yale University Press.

Sick, H. 1997. Ornitologia Brasileira. Rio de Janeiro, Editora Nova Fronteira.

Sydeman, W.J. \& Emslie, S.D. 1992. Effects of parental age on hatching asynchrony, egg size and third-chick disadvantage in Western Gulls. The Auk, 109: 242-248.

Tavares, D.C.; Moura, J.F.; Amorim, C.E. \& Siciliano, S. 2013. Distribution and abundance of the Grey-headed Gull Chroicocephalus cirrocephalus (Vieillot, 1818) in Rio de Janeiro, Southeastern Brazilian coast. Revista Brasileira de Ornitologia, 21(3): 168-175.

Tovar, H.S. \& Ashmole, N.P. 1970. A Breeding record for the Gray-Hooded Gull, Larus cirrocephalus, on the Peruvian Coast. The Condor, 72(1): 119-122.

Yorio, P. 2020. Olrog's Gull (Larus atlanticus), version 1.0. In: Schulenberg, T.S. (Ed.) Birds of the World. Ithaca, Cornell Lab of Ornithology. 